\title{
Erratum to: 8th international workshop on the CCN family of genes-Nice November 3-8, 2015
}

\section{The Publisher}

Published online: 16 August 2016

(C) The International CCN Society 2016

Erratum to: J. Cell Commun. Signal. (2016) 10:87-101

DOI 10.1007/s12079-016-0319-9

In the published online version of the 8th international workshop on the CCN family of genes-Nice November 3-8, 2015, a name was mistakenly included during the production process. The name "C. E. Uzoigwe" should be replaced by A. Perbal, Administrative Secretary of the International CCN Society.

The online version of the original article can be found at http://dx.doi. org/10.1007/s12079-016-0319-9

$\triangle$ The Publisher

Springer Science+Business Media B.V.,

Dordrecht, The Netherlands 